\title{
Suggestions and Solutions on China Marine Education*
}

\section{Qing CAO}

Research Department, Tianjin Maritime College, Tianjin, China

\section{Donghai GAO}

Cruise and Tourism Management Department, Tianjin Maritime College, Tianjin, China

Qingjun MA

English Teaching Department, Tianjin Maritime College, Tianjin, China

\begin{abstract}
With the implementation of China marine power strategy, the quantity and quality of domestic required talents improves rapidly. Accordingly, it is important and urgent to carry out a research on marine culture education from a worldwide point of view.
\end{abstract}

KEYWORD: marine culture; marine education; local resources

\section{THE NECESSITY OF CHINA MARINE EDUCATION}

The 21st century is an ocean century. The construction of China marine power is an important part to realize the great Renaissance of China. The People's Republic of China the twelfth five-year plan for national economic and social development program put forward higher request to marine development of China, National twelfth five-year Marine science and technology development program tries to practice Chinese maritime modernization, to change China from a big country of ocean and shipping the shipping power. The construction of shipping power has a lot to do with the ocean consciousness and the prosperity of marine culture, and this kind of consciousness and culture, must adhere to the global perspective, open and cooperative. The current national ocean consciousness is relatively weak, which has become the bottleneck of China marine power development and construction.

\section{THE MARINE EDUCATION ABROAD}

The development of most western developed countries is closely linked with marine development. Especially in the late 19th century, Alfred Thayer Mahan, an American, put forward "sea power theory", which reveals the close relationship between the national rise and fall and the ocean domination, and the theory of by using marine trade to thrive the country, which had a great influence in afterward world history. Even in the globalization at present, its rationality still exists. The United States, Japan, Europe and other western countries have treated the ocean as a part of lifelong education content. The United States, for example, for 12 years of primary and secondary school of marine science education, United States Congress issued 21st Century Ocean Blue Book which highlighted the marine education to strengthen the awareness of marine environment, enhance the public marine cognition, and train marine scientists from next generation, also laid a foundation for spreading and developing marine culture across the United States.[1] As early as 2003, in Japanese primary and secondary disciplines, the proportion of unit number in the total number of units about the content of water and sea has surprisingly reached $21.7 \%$ and $34.5 \%$.[2]

\section{THE BASIC PRINCIPLES OF DEVELOPING MARINE EDUCATION}

\subsection{Patriotism}

China modern history is actually a history process of maritime policy change and adjustment. Recent China history reminds people not to forget that the decline of modern China is because of ocean decline, on the other hand, the coastal cities like Hong Kong, Shanghai and Tianjin experienced culture exchanges between east and west and became the main hub of modern patriots. China industry, commerce, army, education and all walks of life save the nation from subjugation and thrive to the sea. 


\subsection{Harmonious ocean}

Ocean benefits human, human should also be kind to the ocean. Cooperation and communication should be strengthened between countries, pollution to the sea and confrontation between countries should also be reduced.

\subsection{Universal education}

Marine education should not only be a special education in colleges or universities but also a universal education, covering stages from primary school, secondary school, university to adult age, and contents ranging from science, military, economic, culture to other aspects, laying ideological foundation for the construction of modern ocean power.

\subsection{English application}

Due to historical reasons, common language of oceans and international navigation is English. English communication skills gradually evolve into a life skill of "global village" villagers because of domestic and international education, career and social reasons. In the process of marine education, not only should the language communication be attached importance to, but also their cultural information behind should be paid more attention to, such as religious difference, life difference, etc.

\subsection{Multiple interactions}

Through visible and dominant material culture, we can intuitively feel or distinguish a cultural difference. Implicit culture such as system culture, way of thinking, religious beliefs, and aesthetic taste can also be presented by use of books, clothing, and daily necessities. Cultural education must have diversity and practicality. Culture does not have an accurate or clear standard of classification, but needs concrete things to an abstract description. Marine culture has its own characteristics, including dock culture, concession culture, business culture and so on, which need practice, participation and interaction to perceive.

\subsection{Open interest}

Some cold knowledge related to navigation can cause people's interest to explore and study, for example, the daily hot pepper, corn, tobacco was introduced into China only after great maritime era; the sinking cultural relics of maritime silk road sold at an auction abroad; the unique Mazu Culture of China's coastal region inherits in Tianjin after the Queen of Heaven Palace; the relationship between diet and marine culture; the way of thinking expressed by marine related English words, etc.

\section{SUGGESTIONS AND SOLUTIONS TO CARRY OUT THE MARINE EDUCATION}

\subsection{Government leading}

A. To pay high attention and to establish special actuators

To set up China ocean committee; to start a new period Oceanography and national marine strategic learning activities among the cadres and civil servants of government and army in a proper way; combining civil and abroad experts, to promote international learning and communication in the field of ocean. Such as COSEE - China, Centers for Ocean Sciences Education Excellence, held in August, 2010 in China; increase the salary of marine professional personnel and increase attraction to talents, etc.

B. Construction and maintenance of various museums

To extend the collections and content of natural museum, history museum and other basic museums; to actively construct specialized marine museum, such as Shanghai Maritime Museum, Tianjin National Maritime Museum, Yangjiang Marine SilkRoad Museum in Guangdong, Spring State Oversea Transportation History Museum in Fujian, Putian Mazu Origin Museum in Fujian, Jiangsu Yangzhou fishing culture expo park, etc.; to fully exploit the historical and cultural values of marine cultural relics and sites and ancient architectural structures, such as Zhenghe Memorial Museum in Jiangsu Taicang, Liu Gongdao Sino-japanese War Memorial in Shandong, Tianjin Infusing Loving Ancient Coast Ruins Museum, the Overseas Chinese History Museum of Fujian Quanzhou, etc.

In these places, to popularize Chinese/English bilingual and also multilingual introductions and guides to visitors.

C. To reform college and university marine education, sound marine education system

To solve problems like unsound marine education system, seriously unbalanced education resources, no insurance in education system, unclear education measures, ineffective education mechanism, large gap in equipment funding, lack of talents in designated positions, textbook low coverage content in primary and secondary school, etc.

D. To enhance the publicity on the mainstream media, expand propaganda way and scope

To foster cultural creative industries whose subject is ocean, such as entertainment, exhibitions, publication, animation, etc; to increase the report transparency of surrounding sea situation of China; to carry out exhibitions to warships, research vessels, and national level marine projects.

E. To carry out marine folk festival culture activities

Coastal areas and cities can learn from activities like China's Ocean Culture Festival, Qingdao 
International Seafair, Xiamen International Ocean Week, Xiangshan Start-fishing Festival, to develop the local people's marine cultural life, build brand, create benefit, and make the ocean consciousness deep into hearts.

\subsection{Enterprise assistance}

To visit companies, experience some of the post process, understand the relevance and importance of marine economy to people's life.

\subsection{School support}

To enhance the forwardness and integration of marine subject teaching, and its compatibility with the development of local economy; to strengthen the maritime related practices and organize various visits; to carry out marine reading, experiment, and knowledge competition; to carry out marine environmental protection and marine safety education; to develop school-based marine curriculum with humanistic resources characteristics; to form ocean characteristic culture education in coastal local colleges.

\subsection{Participation of Non-governmental organizations and public welfare organizations}

Out of the industry limitations, to develop the effects of each association and develop publics' activities.

\section{CONCLUSION}

The sea is blue territory. In the era of economic globalization, strengthening the consciousness of sea power, increasing the ocean knowledge and consciously safeguarding national interests become the realistic education problem that the citizens need to pay close attention to. For China, a country back against Eurasian continent with coastlines on the Pacific Ocean, running the ocean is significant to its geopolitics, national security and economic evelopment. In the past history of China it mainly shows the characteristics of loess land culture. Now, contributing national marine education, raising national blue ocean culture awareness and ocean literacy has become the top priority of marine power construction.

\section{REFERENCES}

[1] Deputies proposed marine education should become an important part of primary and secondary education. China Communications News. March 7, 2012

[2] Let marine power concept deeply rooted in the national heart. Guangming Daily. February 17, 2014 (China)

[3] PRC State Council. The People's Republic of China the twelfth five-year plan for national economic and social development program.

http://www.gov.cn/zwgk/2013-01/17/content_2314162.htm

[4] WU You-Sheng: accelerate the reform process marine education. China Ocean News. March 15, 2010 (China)

[5] HU Song, LIU Hui, LI Yong-Pan. American Marine Science Education profiling. Ocean Development and Management.2012 (1). (China) 